International Journal of Agriculture, Environment and Bioresearch

Vol. 5, No. 05; 2020

ISSN: $2456-8643$

\title{
IMPACTS OF OIL EXPLORATION AND PRODUCTION ON PASTORALISMAT BALILA AREA, WEST KORDOFAN STATE, SUDAN
}

\author{
Kawthar Rabih Salih Rabeeh ${ }^{1}$, ElkheirMugadamSalih ${ }^{2}$, Abdelwadoud A. Elkhalifa ${ }^{3}$ and Yahia Ibrahim M. \\ Abutaba $^{4}$ \\ ${ }^{1}$ College of Agricultural Science, University of Dalanj, Sudan \\ ${ }^{2}$ College of Forestry and Range Science, Sudan University of Science and Technology. Khartoum, Sudan \\ ${ }^{3}$ College of Forestry and Range Science, Sudan University of Science and Technology. Khartoum, Sudan \\ ${ }^{4}$ Faculty of Natural Resources and Environmental Statues, University of Kordofan, Sudan
}

https://doi.org/10.35410/IJAEB.2020.5548

\begin{abstract}
This study was conducted at Balila area, West Kordofan State, Sudan in September 2018. The aim of this study was to examine the impacts of oil exploration and production operation on pastoralism at Balila area. Three communities being, Balila, Elshag and Elfrdus were selected for the study. The study employed both primary and secondary sources for data collection. Primary data involved administration of structured questionnaire to 139 inhabitants using simple random sampling. Three focus groups discussions were carried out in each of the three sites. Descriptive statistics were used to analyze the data using SPSS software program (version 22). Data were presented on the basis of frequencies and percentages. Results indicated low human capital development with the majority of respondents $(97.2 \%)$ being illustrate or with basic education. Results revealed that majority of the interviewed inhabitants confirmed adverse effects of oil exploration and production activities on the environment and consequently on their livelihoods. Perception of respondents towards these negative impacts confirmed: decline of soil fertility (82.7\%); shrinkage of rangeland $(79.1 \%)$; dropping in crops yields $(70.5 \%)$; deforestation $(89.9 \%)$; contamination of both surface and groundwater(61.9\%) and increase in morbidity(99.3\%) and mortality $(87.8 \%)$ among livestock. Further, community individuals agreed that they are vulnerable to health hazards such as cancer, kidney failure, skin irritation, and miscarriage and fertility problems.
\end{abstract}

Keywords: Pastoralism, oil, exploration, WestKordofan.

\section{INTRODUCTION}

Pastoralism occurs in more than 100 countries on about $25 \%$ of Earth's land area and supports about 200 million households and herds of nearly a billion animals, including camels, cattle, and smaller livestock that account for about $10 \%$ of the world's meat production (FAO, 2001).It can be interpreted that nomadism or the movement of stock according to season is a form of grazing management system which is still being carried out in many settled communities such as the Turkaman of the old Soviet Union, and among most of the Middle East countries. The only difference from Sudan and may be the Sudanese Sahelian countries is the fact that in these 
countries, these seasonal movements are controlled and the grazing utilization is conditioned by the availability, the condition, and the readiness of grazing for livestock use. Pastoralism provides very important ecological services, such as primary production, biodiversity conservation, and erosion control (FAO, 2019). Pastoral nomads depend on range lands and move with stock to where feed and water are available but within specific geographical zones. In Kordofan, Darfor, Central and Eastern regions this system is considered as the main live stock production for meat for real demand and for export.

The rise of oil production in Western Kordofan State has disrupted pastoral livelihoods in oil producing areas and diminished the importance of livestock production for the Sudanese economic (Leonard, 2007).

There is no doubt that the exploitation of oil has many benefits to the national economy, but we cannot lose sight of the effects it has on the environment and change the components of the natural resources of the area as well as its social and economic impacts. Some changes in the soil appeared with a clear decrease in the number and quality of plants and that corresponds to (Wyszkowski and Ziolkowska, 2008). The flow of oil over large areas of rangeland has had the effect of reducing and changing.

The above features are very much influenced by anthropogenic factors, which include the contamination of soil with petroleum-derived products. Changes in some soil properties resulting from contamination with petroleum-derived substances, and particularly those related to physicochemical composition, brings about some changes in the biological composition of soil which, inconsequence, can lead to water and oxygen deficits, as well as to a shortage of available forms of nitrogen and phosphorus (Wyszkowska and Kucharski, 2000).

Soil constitutes the living environment not only for people, but also for plants and animals and through its functions provides for the needs of the natural environment (kuch and Bavumiragira, 2019). The contamination of the natural environment by petroleum substances contributes to the degradation of land, and the occurrence of many spot and area sources of contamination overtime results in the creation of various integrated underground environments contaminated with these substances (Sztompka,19 99).Particularly dangerous soil contaminations include pollution with petroleum, which is very often observed in municipal soils, around industrial plants and in areas where petroleum and natural gas are obtained (Adam et al.,2002; Clark, 2003).

\section{MATERIALS AND METHODS}

\section{The study area}

Balila area is located atWestKordofan State in the central part of Sudan extending from $11.250 \mathrm{~N}$ to $16.670 \mathrm{~N}$ latitudes and from 27.500 E to $32.420 \mathrm{E}$ longitudes. The State covers an area of approximately 114,000 Km2 (Guuma, 2017). The area is a forested land scatteredwith some plains, valleys and sand dunes which is consideredas one of the poor savanna belts. The two main livelihood systems have traditionally been pastoralism and subsistence farming.Pastoralist 
communities in the area include both nomadic and semi-nomadic (transhumant) cattle, sheep and goat herders.

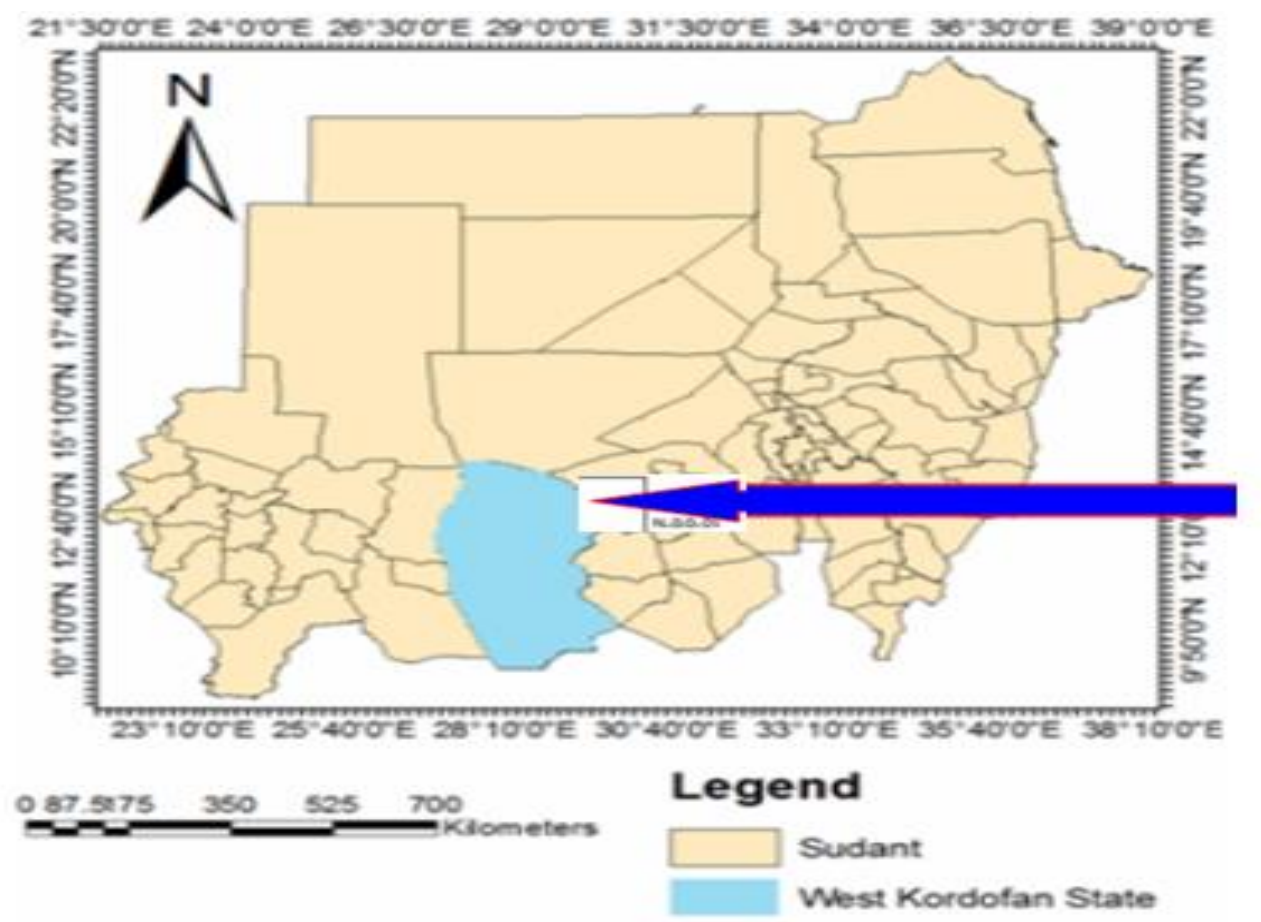

\section{Data collection}

Data collection made use of both primary and secondary sources. Primary data relied on administration of 139 copies of structured questionnaire to inhabitants using simple random sampling, and on groups discussions with local leaders and relevant people in the target population..Three communities, Balila, Elshag and Elfrdus villages were selected for the study. Secondary data were obtained from relevant sources.

\section{Data analysis}

Descriptive statistics were used to analyse the collected data using SPSS software program (version 22). Data were presented on the basis of frequencies and percentages..

\section{RESULTS AND DISCUSSION}

The majority (36.7\%) of the respondents were between the ages of (30-45) years, while (25.9\%) were (45-55) years of age. The number of males sampled was higher (64\%) as men are more willing to participate than women (Table 1).Result also indicated low human capital development in Balila area because the majority of the respondent $(74.9 \%)$ had no regular education. This high rate of illiteracy may be attributed to unavailability of schools and lack of interest of many families to educate their sons. According to table 1 herding constitutes the main 
occupation for almost $70.5 \%$ of the respondents whereas agro-pastoralists constituted about $23.0 \%$. New jobs have appeared in the area such as casual labors working in the oil company and petty trade. Livestock selling constitute the main source of income (79.9\%).In order to increase their purchasing power some herders liquidate some of their livestock resulting in reduce of herd number. Further, $14.4 \%$ of respondents agreed that selling agricultural crops such as watermelon and okra have greatly contributed tohouseholds' subsistence.

Table 2 shows the perception of respondents towards change in soil and plant due oil exploration and production. About $82.7 \%$ of respondents confirmed that their soil has been degraded. About $79.1 \%$ of respondents confirmed decrease in grassland production, whereas $70.5 \%$ agreed that there was reduction in crop production in farmlands. Pollution of grasslands and farms is a well-known phenomenon (Ekekwe, 1981). The flow of oil over large areas of rangeland has had the effect of reducing and changing its flora (Wyszkowski and Ziolkowska, 2008).

The obtained results could be explained by the fact that oil reduces the soil fertility such that most of the essential nutrients are no longer available for plant and crop production. Oil spills has adverse effects on nutrient level and fertility status of the soil (Abii and Nwosu, 2009).Abosede, 2013 reported that oil pollution might affect soil physical properties. Pore space might be blocked which could reduce soil aeration and water infiltration and subsequently affect plant growth. Oil exploration and development at Balila area adversely affected the pastoral communities' livelihood by reducing the availability of pastures and hereby resulting in reduction in herds' number and increase of morbidity and mortality of livestock.

The adverse effects of oil activities on the environment arise from oil leakages, gas flaring and the escape of other chemicals used in the process. According to groups discussions local inhabitants have noticed the presence of chemical and chemical containers buried in the soil. Oil spills render the soil toxic and unproductive. Spilled oil which is denser than water, reduces and restricts permeability: organic hydrocarbons which fill the soil pores expel water and air, thus depriving the plant roots the much-needed water and air (Brain, 1977).Adam et al., 2002; and Clark, 2003confirmed the adverse effects of oil on soil characteristic and vegetation cover. Accordingly, a necessity arise for the adoption of remediation technique to restore contaminated soil. The company (Petro energy) involved in oil production at Balila area treat the contaminated soil with cow droppings to break down pollutants.Kelechi, et al. 2008, reported that the addition of cow dung to oil contaminated soil make such contaminated soils useful for agricultural activities and improve growth performance of the plants.

Destruction and disappearance of some forest tree species was observed by majority of respondents ( $89.9 \%$ ). noticed some changes in forests trees of the area. $23.2 \%$ of respondents confirmed disappearance of certain tree species such as Albiziaamara, whereas $72.8 \%$ confirmed absence of natural regeneration. Forest destruction results from illegal tree cutting

Percentages distribution of respondents according to the impact of oil exploration and production on water resources in Balila area was given in Table 3.A total of $89.2 \%$ of respondents agreed that wells and hafirs are the main water sources for humans and animals in Balila area. Moreover, about $79.9 \%$ of respondents noticed an increase in the number of water points since the beginning of the oil activities in the area. Water availability might be considered as a positive 
Vol. 5, No. 05; 2020

ISSN: $2456-8643$

contribution of oil activities to local communities. The oil company drilled more than 80 water wells in the area (Petro- Energy Company 2016).Moreover, the construction points dug by the company to obtain earth for road network construction served as additional water points.

Pastoralists believe that the oil industry has contaminated water supplies and pastures, and say that their cattle are suffering as a result, especially as regards fertility (Pantulianoet. al., 2009). Table 3 showed also, that about $47.5 \%$ of respondents confirmed change in the quality of the water. Further, $86.1 \%$ of respondents confirmed contamination of both surface and underground water as a result of oil activities. When oil spills occur it seeps into the ground and becomes mixed in the underground water system. It has been found that polluted underground water nodoubt takes many years before it can be remedied. Yet this underground water moves into streams and wells which are the only sources of local water supply in the community which results in the rise of water-borne diseases ((Kuch and Bavumiragira, 2019)

The drilling process is known for contaminating drinking water sources with chemicals that lead to some types of diseases such as cancer, birth defects and liver damage.During drilling operations, the seepage of effluent water to the surrounding areas is a major source of pollution. .Oil activities in pastoral areas altered the natural drainage system due to road construction against the normal cantor. This on one hand lead to drying up of some seasonal water bodies and on the other hand accumulation of watermelon roadsides caused death of trees and reduced cultivable land. Hence, rangeland farmland, forests and wildlife habitat were miserably affected (khaleel and Ahmed, 2014).

The perception of respondents towards the effects of oil industry activity on public health in Balila area was given in Table 4. About $86.4 \%$ of respondents confirmed appearance of some diseases as a result of oil activities and a total of $94.2 \%$ noticed increase in the number of patients while $89.9 \%$ of respondents confirmed increase in death rate in the community. Further, $97.1 \%$ of respondents confirmed appearance of unfamiliar diseases such as cancer, kidney failure, and skin irritation diseases. Chemicals used and derived wastes in oil exploration and production operations proved to be highly harmful to human health (Maria, et al. 2017).Local inhabitants who live aroundBalila oil fields relate the emergence of such strange diseases and other serious conditions in themselves and their children to the activities of the oil industry. People who reside near oil exploration activities may be exposed to toxins from gas flares or oil spill and hence increasing the risk of developing certain types of cancer (Pauline, et. al.2019). Similarly, Atubi, 2015, reported that in Nigeria, people living around oil fields agreed that they were vulnerable to health hazards.92.1\% of respondents noticed the presence of fertility problems since the arrival of the oil industry in the area.Atubi, 2015 who worked in Delta State in Nigeria reported that because of oil operations the release of toxic materials and disposal of industrial wastes may affect the fertility of the inhabitants in such away the fecundity fall and the birth of abnormal babies may increase.

Rubbish pits dug by the operating company for disposing domestic and industrial wastes, such as empty chemical containers, are not properly managed. During rains these oil- derived wastes seep into the ground and become mixed with underground water or they are washed by runoffs into other water points leading to contamination of water resources. Some of the empty 
chemical-containers escape from the industry into the villages where they are used for storing drinking water. These containers could be a major source of water pollution.

Table 5 shows he impacts of oil activities in Balila area on animals. The majority of respondents agreed that there is decrease in livestock number, increase of diseases and increase in mortality rate among livestock $(88.5 \%, 99.3 \%$ and $87.8 \%$ respectively)locals are convinced that oil activities have adversely affected rangeland, and that most livestock losses experienced in the last few years are due to water contamination and poor waste disposal. Polluted water is said to have become a threat to animal health with livestock numbers decreasing steadily since drilling began (Pantulianoet. al., 2009).Never he less.

\section{CONCLUSIONS}

The study has revealed that activities associated with oil exploration and production operation in Balila area have local significant impacts on the environment and subsequently on the livelihoods of the communities. Most of the respondents confirmed increase of soil infertility, reduce in available pastures and farmlands resulting in reduction of both herds' numbers and crop production. Contamination of surface and ground water due to oil activities have increased morbidity and mortality rates among livestock. Because of Air pollution and contaminated domestic water communities aroundBalila oil field are vulnerable to health hazards. The emergence of strange diseases such as cancer, kidney failure, miscarriage, skin irritation and fertility problem was observed.

\section{REFERENCES}

Abii, T. A. and Nwosu, P. (2009). The effect of oil-spillage on the soil of Eleme in Rivers State of the Niger-Delta Area of Nigeria. Research Journal of Environmental Science, Vol.3 No. 3

Abosede, E. E. (2013). Crude oil pollution of some soil physical properties.Journal of Agriculture and Veterinary Science.6(3).

Adam, G.K. Gamoh, D.G. Morris and H. Duncan (2002) Effect of alcohol addition on the movement of petroleum hydrocarbon fuels in soil. Science of the Total Enverionment. 286(1/3): $15-25$.

Atubi, A. O. (2015). Effects of oil spillage on human health in producing communities of Delta State, Nigeria. European Journal of Business and Social Science, Vol 4 No. 8

Brian, J. K. (1979). Soil Processes. Unwin Hyman, London.

Clark, C.J.II., (2003) Field detector evaluation of organic clay soils contaminated with fuel. Environmental Forensics, 4(3): 167-173.

Ekekwe, E., 1981. The funiwa- oil well blowout. In: Proceedings of International Seminar on Petroleum and the Nigeria Environment NNPC, Warri. 
Vol. 5, No. 05; 2020

ISSN: $2456-8643$

FAO (2001) Pastoralism in the new millennium. Animal production and health paper no 150. UNFood and Agriculture Organization, Rome.

FAO, (2019) Technical Assistance to Support Food Security and Livelihoodsof the Pastoralist Groups in West Kordofan, Sudan.

Guuma, Ismail Adam (2017) Application of Remote Sensing and GIS in Land Use and Land Cover Changes in West Kordofan State- Sudan, MSc. Thesis, University of Kordofan,Sudan.

Khaleel M. S. and Ahmed E. M. (2014).Impacts of Oil Exploration on the Livelihoods of Agropastoralists in Western Kordofan State - Sudan.Journal of humanities and SocialScience.Vol 19 (1).

Kelechi, L. Njoku, Modupeo.Akinola and Bola O. Oboh (2008(.Growh and performance of Glycine max L. (Merrill) grown incrude oil contaminated soil augmented with cow dung. Life Science Journal, Vol. 5 No. 3.

Kuch, S. G. and Bavumiragira, J. P. (2019).Impacts of crude oil exploration and production on environmentand its implications on human health, South Sudan Review. International Journal of Scientific and Research Publications, vol 9(4)

Leonard, David K. (2007). The Political Economy of Livestock And Pastoralism In Sudan, Institute for International Studies University of California, Berkeley Research Director: David K. Leonard Institute of Development Studies (Sussex).

Maria I, R. ; Ana P. A.;Santiago S. and Natalia B. (2017). Contamination of oil crude extraction - Refinements and their effects on human health.Journal of Environmental Pollution, 231.

PantulianoS.;Egemi O.;Fadlalla B.; Farah M. and Abdelgadir M. E. (2009). Put out to pasture. War, oil and the decline of MesseriyyaHumr pastoralism in Sudan.Humanitarian policy Group.Overseas development institute, London.

Pauline M. ;Olzhas D. ; Zhaxybek N. ;Ussen K. and Dinara K. (2019). The effect of exposure to crude oil on the immune system. Health implications for people living near oil exploration activities. International Journal of Environmental Health, $1-26$.

Petro-Energy Company(2016).Community Development Book.PDOCandPE Tower AlSunutAera .Almogran.Khartoum-Sudan

Sztompka, M., (1999) Biodegradation of engine oil in soil, ActaMicrobiologicaPolonica, 48(1): 185-196.

WyszkowskaJ.and.KucharskiJ.(2000).Biochemical properties of soil contaminated by petrol.Polish Journal of Environmental Studies,9(6):479-485.

WyszkowskiM. and Ziókowska A. (2008).effect of petrol and diesel oil on content of organic carbon and mineral components in soil. American-eurasian Journal of Sustainable Agriculture, 2(2). 
Table: 1 Personal characteristics of respondents

\begin{tabular}{|c|c|c|}
\hline Personal characteristics & Frequency & Percentage $\%(\mathrm{n}=139)$ \\
\hline \multicolumn{3}{|l|}{ Age } \\
\hline $25-35$ & 22 & 15.8 \\
\hline $35-45$ & 51 & 36.7 \\
\hline $45-55$ & 36 & 25.9 \\
\hline More than 55 & 30 & 21.6 \\
\hline \multicolumn{3}{|l|}{$\operatorname{sex}$} \\
\hline Male & 89 & 64 \\
\hline Female & 50 & 36 \\
\hline \multicolumn{3}{|l|}{ Education } \\
\hline Illiterate & 104 & 74.9 \\
\hline Primary/Basic & 31 & 22.3 \\
\hline Secondary & 4 & 2.8 \\
\hline \multicolumn{3}{|l|}{ Occupation } \\
\hline Herder & 98 & 705 \\
\hline Agro-pastoralist & 32 & 23.0 \\
\hline Casual labor & 6 & 4.3 \\
\hline Trade & 3 & 2.2 \\
\hline \multicolumn{3}{|l|}{ Sources of income } \\
\hline Livestock sales & 111 & 79.9 \\
\hline Crop sales & 20 & 14.4 \\
\hline Petty trade & 8 & 5.7 \\
\hline
\end{tabular}


Table: 2 Impact of oil activities on soil and plant in Balila area.

\begin{tabular}{|c|c|c|}
\hline Criteria & Frequency $(\mathrm{n}$ & $(\%)$ \\
\hline Soil contamination & 115 & 82.7 \\
\hline Yes & 24 & 17.3 \\
\hline No & & \\
\hline Grassland production & & \\
\hline decreased & 110 & 79.1 \\
\hline increased & 112 & 8.6 \\
\hline No change & 17 & 12.3 \\
\hline Causes of grassland decline & & \\
\hline Oil activities & 97 & 69.8 \\
\hline Reduce of rangeland area & 32 & 23 \\
\hline Low rainfall & 10 & 7.2 \\
\hline Farmland production & & \\
\hline decreased & 98 & 70.5 \\
\hline increased & 41 & 29.5 \\
\hline Forest tree cover & & \\
\hline changed & 125 & 89.9 \\
\hline No change & 14 & 10.1 \\
\hline Causes of change & & \\
\hline Destruction of tree species & 48 & 34.5 \\
\hline Absence of natural regeneration & 91 & 65.5 \\
\hline Purposes for tree cutting & & \\
\hline charcoal & 52 & 37.4 \\
\hline Road construction & 38 & 27.4 \\
\hline
\end{tabular}


International Journal of Agriculture, Environment and Bioresearch

Vol. 5, No. 05; 2020

ISSN: $2456-8643$

building

31

22.3

Oil pipe route

18

12.9

Table: 3 impact of oil activities on water sources in Balila area

\begin{tabular}{|c|c|c|}
\hline Criteria & Frequency $(\mathrm{n}=139)$ & Percentage (\%) \\
\hline \multicolumn{3}{|l|}{ Water sources } \\
\hline Hafir & 9 & 6.5 \\
\hline Wells & 77 & 55.4 \\
\hline Rahad & 3 & 2.2 \\
\hline Hafir and wells & 38 & 27.3 \\
\hline Hafir, wells and Rahad & 12 & 8.6 \\
\hline \multicolumn{3}{|l|}{ Water points: } \\
\hline Increased & 111 & 79.9 \\
\hline Decreased & 15 & 10.8 \\
\hline No change & 13 & 9.4 \\
\hline \multicolumn{3}{|l|}{ Water quality } \\
\hline Changed & 73 & 52.5 \\
\hline No change & 66 & 47.5 \\
\hline \multicolumn{3}{|l|}{ Causes of water contamination } \\
\hline Oil industry wastes & 86 & 61.9 \\
\hline Oil spill & 22 & 15.8 \\
\hline Use of the industry containers & 31 & 22.3 \\
\hline
\end{tabular}


Table: 4 impact of oil exploration and development on human health in Balila area

\begin{tabular}{|lcl|}
\hline Criteria & Frequency $(\mathrm{n}=139)$ & Percentage (\%) \\
human diseases & 131 & 94.2 \\
Increased & 8 & 5.8 \\
No change & 135 & 97.1 \\
\hline Appearance of new diseases & 4 & 2.9 \\
Yes & & \\
No & 42 & 31.1 \\
\hline New diseases & 36 & 25.9 \\
Cancer & 34 & 24.5 \\
Kidney failure & 27 & 19.5 \\
Skin irritation & 128 & 92.1 \\
Miscarriage & 11 & 7.9 \\
\hline Appearance of fertility problems & 125 & 89.9 \\
Yes & 10.1 \\
No & & \\
\hline Human death rate & 14 & \\
Increased & & \\
No change & 125 \\
\hline
\end{tabular}

Table: 5 Impacts of oil activities on animal in Balila area

\begin{tabular}{|lll|}
\hline criteria & Frequency $(\mathrm{n}=139)$ & Percentage $(\%)$ \\
livestock numbers & & \\
$\quad$ declined & 123 & 88.5 \\
increased & 16 & 11.5 \\
\hline
\end{tabular}


International Journal of Agriculture, Environment and Bioresearch

Vol. 5, No. 05; 2020

ISSN: $2456-8643$

\begin{tabular}{|lll|}
\hline $\begin{array}{lll}\text { Increase in livestock disease } \\
\text { Yes }\end{array}$ & 138 & 99.3 \\
No & 1 & 0.7 \\
\hline Mortality rate among livestock & 122 & 87.8 \\
Increased & 17 & 12.2 \\
Decreased & 27 & \\
\hline Causes of morbidity and mortality & & 21.8 \\
Contaminated water & 8 & 6.5 \\
Oli derived wastes & 89 & 71.8 \\
Unknown & 129 & 92.8 \\
wildlife & 10 & 7.2 \\
Decreased & & \\
Increased & & \\
\hline
\end{tabular}

